\title{
INCREASING STUDENTS' VOCABULARY ACQUISITION BY MASTER AND MASTERY CARDS GAME
}

\author{
${ }^{1}$ Venolia Sahrin; ${ }^{2}$ Mulyadi Hasan \\ 1,2,Universitas Bengkulu \\ Corresponding email: venoliasahrin@gmail.com
}

\begin{abstract}
The objective of this research is to explain how the Master and Mastery cards game improve students' vocabulary acquisition and participation learning process of applying Master and Mastery cards game in teaching vocabulary for tenth grade students of a vocational school. This research was carried out with a classroom action research design. Field notes were the instruments to collect the qualitative data. While vocabulary test and gained the quantitative data that strengthen the quantitative data. The increasing of the test 1 and test 2 was 22.83 point. Responding to that result the teacher-researcher decided to stop the cycle at cycle two. According to the researcher and co-observer's observation students participated actively while playing Master and Mastery vocabulary cards game. This research significantly increased students' vocabulary acquisition as well as participation.
\end{abstract}

Keywords: Master and Mastery Cards Game, Vocabulary Acquisition, Participation

\section{INTRODUCTION}

Tourism and hotel accommodation are two of the most prospective sectors growth in Bengkulu, Indonesia. With beautiful natural scenery and stunning heritage, Bengkulu has become a province in Indonesia that is attracting a growing number of foreign visitors. Appropriately, it is necessary for the government to train society especially young generation to be able to handle or even manage any service industry related to those sectors.

In this case, one of the government's supports in boosting the quality of future workers is administering Vocational school. Vocational school has had a big impact in preparing their students to be ready and skillful future workers. SMK N 7 as a vocational school in Kota Bengkulu is preparing the best quality of graduates in order that they have the capability to get a job.

The researcher has interviewed the English teacher Mrs. Ita Isnaniah, S.Pd. According to her explanation, during the teaching-learning process at hotel accommodation students, she was facing a situation where the students need to require great effort in following English lesson. Right after 
that, the researcher doing classroom observation in the guided teaching phase. Here the researcher found that the difficulties were caused by some factors as mention below:

1) The teacher used some methods in teaching such as teacher explanation, group discussion, role play and presentation. Nevertheless, it makes some students become less active and reluctant to get involved in the process of learning. Only few of group member doing the task and the rest group member are just keep talking or doing anything else.

2) Limited multimedia and facilities provided by the school make the students have less interest and motivation in following the learning process. In this school teachers do not use any tools like LCD projector and audio-system for delivering new material or show any audio-visual media. During individual supervised teaching, the researcher use printed picture, text, flashcard, audio speaker for listening, and white board as the media.

3) The students have limited vocabulary. It can be seen in learning activity, when the students were allowed to deliver their opinion or to present their work in front of the class, many students chose to speak Bahasa Indonesia rather than English, sometimes they used Bengkulu dialect. Even if they were speaking English, they usually repeated the same words in constructing speech.

The researcher supposed these cases as problems which were needed to be solved. In order that the students can create a meaningful communication, they need to have good language competences: listening, speaking, reading and writing. All of these aspects depend on the extent of the vocabulary they have already.

A British linguists Wilkins (1981) stated "While without grammar little can be conveyed, without vocabulary nothing can be conveyed." It is because in real life communication listener could still understand what speaker said even if the talks uttered grammatically wrong. In the other words the speaker and the listener need to have the same understanding about vocabulary of target language to convey the message in a communication.

In teaching vocabulary for English as Foreign Language (EFL) learners, teachers may use various techniques and strategies. Jeremy Harmer in his book "how to teach English" states that a teacher must have a more creative ways of teaching students. It can be done by giving students a challenging variety of languages; giving exposure even inspiring teachers are asked to give the game which can arouse the children's motivation to be more ready to learn. 
There are several media that can be used in learning activity, such as picture cards or card game. These media are appropriate for teaching vocabulary to students because they are excited to study through playing. Likewise, Hafield (1985) in Daryanti (2008) stated that "Emphasize in the use of game for language learning". Supporting that statement, several researchers have proven that vocabulary game can increase students' vocabulary acquisition as well as their participation in group work or classroom activity.

In this research, the researcher presented an innovation for additional learning media that can be applied by English teacher in teaching vocabulary. It was Master and Mastery Cards game, the third series of "Belajar Bahasa Inggris dengan Kartu". It consists of one instructions book and five boxes of cards. Two boxes of Master and Mastery Cards Noun-Meaning and the other three are Master and Mastery Card Part of Speech. The creator of Master and Mastery Cards game, Yusuf (2008) stated that this cards game is not only designed for University students, but also high school students, to test their ability in comprehending English vocabulary. Asmar (2008) in Yusuf (2008) said that "Master and Mastery Cards Game is one way to increase ability in using English. In learning process we need a new pattern of learning to avoid boredom. Gaming makes students strongly motivated in studying English more." As a result, they accept and acquire English vocabulary easier without any pressure. On the other side, teaching English vocabulary using game can help teacher in giving reinforcement while teaching learning process. The students that are reutilized to play Master and Mastery Cards game will acquire many more vocabulary. Automatically that vocabulary will be saved in their long term memory.

Judging from the explanation above the researcher conducted a study about this technique in teaching and learning process at $10^{\text {th }}$ grade of SMK N 7 Kota Bengkulu, in order to know how Master and Mastery Cards game improves Students vocabulary acquisition. The research title is Increasing Students' Vocabulary Acquisition by Master and Mastery Cards Game at X PH 2 of SMK N 7 Kota Bengkulu academic year 2018/2019.

Considering the background of the study above, the researcher identifies several problems in teaching vocabulary, they are (1) Limited multimedia and facilities provided by the school make the students less interest in engaging in the learning process. (2) The students have limited vocabulary. This research is aimed to answer the following question:

1) Can Master and Mastery vocabulary cards game can increase students' vocabulary?

2) How Master and Mastery vocabulary cards game improve students participation in learning English? 


\section{METHODS}

\section{Research Design}

The design of this research is classroom action research. Action research is a form of collective self-reflective inquiry undertaken by participants in social situations in order to improve the rationality and justice of their own social or educational practices, as well as their understanding of these practices and the situations in which these practices are carried out.

The approach is action research when it is collaborative, though it is important to realize that the action research of the group is achieved through the critically examined action of individual group members (Kemmis and McTaggart, 1988:5).

\section{Research Subject and Setting}

The subject of this research was the students of X PH 2 hotelier major of a Vocational School in Bengkulu, Indonesia. This class consisted of 25 students. Every student has the different characteristics and academic background. There is an excellent class of each grades in this school. But, generally, they were equal on average of ages, social status, and domicile. The research has been conducted on 5, 6, 12, and 13 of September 2018 in a vocational school in Bengkulu, Indonesia.

\section{Research Instruments}

In this research, researcher used three instruments to collect the data. They are vocabulary tests, observation checklist that is completed with field note or memo. The qualitative data has been gotten by using observation checklist. While the vocabulary tests which were prepared by the researcher are used to gain the quantitative data.

\section{FINDINGS}

\section{Cycle One}

The preparation of the research began since August 2018. The teacherresearcher prepared the media which were two boxes of Master and Mastery cards game that would be used in the action. After that the teacherresearcher designed the lesson plan that was adjusted with the syllabus of the lesson. After designing the lesson plan teacher-researcher prepared the vocabulary tests instrument and observation checklist. And the last, asking for a colleague's help in observing the implementation of this action research.

The first meeting for cycle one was held on Wednesday, September $5^{\text {th }}$ 2018. And the second metting was at 02.30 p.m on Thursday, September $5^{\text {th }} 2018$ was the second meeting for cycle one. When the teacher and coobserver were entering the class, as usual it was so crowded. After 
disciplining the class, teacher greeted the students, checking the students' presence and opened the lesson by telling about the importance of learning English vocabulary if they want to be able to speak English. Then, the teacher introduced one of many ways to learn English vocabulary which is Master\& Mastery Cards Game.

The teacher showed and explained the rules in playing that cards game in detail. That day was the first time for the students to play the Master and Mastery cards game. Firstly, the students were divided into a group of 3 or 4 . Some students as the players and one another have a role as a rater. The game time was set for 30 minutes only. The cards were given to the students. One of the group members shuffled the cards and divided them to every player.

In administering the first test, the teacher considered that it is important to set the students in a comfortable classroom atmosphere. Under the circumstance which was so hot in the classroom, the teacher invited the students to go outside and enjoyed the wind blowing. In order that, the students could do the test well. After they have gotten their own place, the teacher distributed the test papers to them. In answering the test, there were still the students who were discussing about the tests. Then the teacher stopped their talk. At last, the tests continued until the end of the time limit.

According to the first vocabulary test result, the teacher researcher found out that the students' average score of the first test was 62.17. The highest score achieved was 80 . And there were six students got the lowest score which was 50 . From that calculation there only $65.2 \%$ students pass the test from minimum score 70 . Consequently, the researcher concluded that the students' achievement in score was needed to be improved more.

For the next cycle the teacher-researcher would let he students play with the vocabulary cards game in longer time in order that they have longer engaging process to the vocabulary lists from the Master and Mastery cards game. For additional triggers in the action process the teacherresearcher would like to give some rewards for every winner from each group.

\section{Cycle two}

After conducting the first tests and gaining the reflection of cycle one, the teacher researcher continued to the cycle two. The first and second meetings for cycle two were conducted on September 12th $-13^{\text {th }} 2018$. On the first meeting the students played the cards game in the last 30 minutes before the lesson ended. The teacher divided them into groups and they played the cards for several rounds. At that time the students looked like enjoy the game. They made noisy in the classroom but it was not any matter at all. After the gaming time, the teacher asked the students' perception about the 
game. Some positive responses are raised from several students. They said that it was fun and enjoyable.

After gaining the second data which were from observation checklist and second vocabulary tests. The researcher interpreted that the result showed the significant improvement. It can be seen from the second vocabulary test score. The average of students' second test score was 85 . It means there are 22 improved point than previous score. In total there are $95.6 \%$ students pass the test while only $4.4 \%$ student could not reach score 70. It was much more better than before in cycle 1 .

Furthermore, the students attitude toward classroom activity was improved and less confusion in play the cards game. The existance of rewards for the winner in cycle 2 affected the students' motivation to learn more the vocabulary list of the Master and Mastery cards game. Ther were more competitive in playing while learning the words list they were playing. By saying that, the teacher researcher decided to end the cycle at the second cycle.

\section{DISCUSSION}

The test result is used to find out how much students have acquired the vocabulary they had learnt before. Based on the first vocabulary tests result, the teacher researcher found out that students' test average score was 62.17. The highest score achiever was Astrid, Cica and Riken, they got 80. And there were six students got the lowest score which was 50. It can be concluded that the students' achievement in score was needed to be improved more.

The data obtained after correcting the test 2 were; the average score of tests 2 was 85; the highest score was 100 and the lowest was 60 . There was a significant improvement between the tests 1 that was conducted in cycle one and tests 2 that was conducted in cycle two. The increasing of the test 1 and test 2 was 22.83 point.

Responding to that result the teacher-researcher decided to stop the cycle at cycle two. The findings of this research are in line with the mentioned studies. This research proves that the use of Master and Mastery cards game significantly improve students' vocabulary acquisition as well as participation.

The pleasure atmosphere in classroom while playing the cards game could make the students easier proceeds information into their mind. As what Krashen (2003) state that Environments that have positive vibes where students feel welcome, promote more learning for the students. Media also can help students to process information without excessive explanation from the teacher in classroom activities. The boredom in learning has been 
minimized by the enjoyable activity which was playing Master and Mastery vocabulary cards game.

\section{CONCLUSION AND SUGGESTION}

According to the researcher and co-observer's observation, students participated actively while playing Master and Mastery vocabulary cards game in groups. The students were so excited during the learning-playing time in classroom had better by treatments. Similarly, the result was found that there was a significant improvement between tests 1 of cycle one and test 2 in cycle two. So it can be concluded that Master and Mastery cards game leads the students to learn better. They who were playing Master and Mastery cards game got more experiences to acquire bit of language into their brain. They tend to learn more active in the teaching and learning activity. In other words, the students who were given treatment using the vocabulary cards got higher chance to interact with the words while they were playing. Psychologically, the pleasure atmosphere in classroom while playing the cards game could make the students easier proceeds information into their mind.

Having presented some conclusions, the researcher would like to propose several suggestions for the teacher to use games in teaching English, here there are some suggestions:

1) Teachers should be able to support students to learn English as much as possible so that they are motivated to study English, the games techniques using Master and Mastery cards game can be used as the media in the teaching-learning process of English.

2) The researcher recommends the English club in the school to provide Master and Mastery cards, so that the members can play it in their spare time. Moreover, it is better for the students to have their own cards, so that they can learn English vocabulary while playing cards game anytime.

For further researchers, it will be a pride, if they would like to use this research as a reference or conduct deeper investigation about Master and Mastery cards game in their teaching English vocabulary in another school.

\section{REFERENCES}

Burns. P.C. and Broman, B.L. 1975. The Language Arts in Chilhood Education. Chicago: Rand Mc Nally College Publishing Company.

Daryanti. 2008. Teaching Vocabulary Using English Crossword Puzzle as an Alternative Medium to Improve Vocabulary Mastery: An Action Research at SDN 1 Badakarya Banjarnegara.Research Paper, School of Teacher Training and Education Muhammadiyah University of Surakarta. 
Hamalik, Oemar. 2010. Dasar - Dasar Pengembangan Kurikulum. Bandung: Alfabeta.

Hornby. (1995). Advance Learner's Dictionary. New York: Oxford University Press.

Kemmis, S., \& McTaggart, R. (1988). The action research planner (3rd ed.). Victoria, Australia: Deakin University Press.

Kemmis, S., \& McTaggart, R. (2000) Participatory Action Research. In N. Denzim \& $Y$.

Kemmis, S., and Mc. Taggart, R. 1982. The action Research Planner. Victoria, Australia: Deakin University Press.

Kosim, N. (2013). Improving the students' vocabulary mastery through flashcards. Jurnal Pendidikan dan Pembelajaran 2 (9). Pontianak: Universitas Tanjungpura. Downloaded from http://jurnal.untan.ac.id/index.php/jpdpb/article/view/3376.pdf

Krashen, S. (1982). Principles and Practice in Second Language Acquisition. 10,15-16. Los Angeles: University of Southern California. Pergamon Press Inc.

Krashen, S. (2003) Principles and Practice in Second Language Acquisition. University of Southern California

Krashen, S. (2004) The Power of Reading. Portsmouth, NH: Heinemann.

Lincoln (eds), Handbook of qualitative research (2nd ed, p.595). thousand Oaks,CA:Sage.

Martin, p. (2010) Vocabulary acquisition. University of Victoria. Retrieved on June 24th from www.uvic.ca/-stemed/2010-archievesitvocabularyacquisition.pdf

MCCARTEN, J. Teaching Vocabulary: Lessons from the Corpus, Lessons for the Classroom. Cambridge: Cambridge University Press, 2007.

Thornbury, S. (2002). How to Teach Vocabulary. Malaysia: Pearson Logman.

Venolia. (2016) A Descriptive Study on The Effect of Teaching Master EMastery Cards Game Toward Students' Vocabulary Aquisition (A Quasi Experimental Research at Tenth Grade of SMK N 1 Kota Bengkulu Academic Year 2015/2016). Bengkulu: Universitas Bengulu.

Wantini, D. (2010). Improving Students' Vocabulary Mastery Using Realia. Surakarta: Sebelas Maret University.

Wilkins, D.A. 1981. Second Language Learning and Teaching. London: Edward Arnold Publisher.

Yusuf, S., and team. (2008). Belajar Bahasa Inggris dengan kartu Master $\mathcal{E}$ Mastery. Jakara: Kawah Pustaka.

Zuharoh, A. (2014). Improving Students' Vocabulary Mastery by Using Karuta Card Game (A Classroom Action Research of the Seventh Grade Students of SMP N 2 Gebog Kudus in the Academic Year 2013/2014. Muria Kudus University. 